\title{
The Effectiveness of Madrasah Head Leadership Competency in Increasing Educational Quality in Madrasah Tsanawiyah Private Vocational School, Al Manar Medan
}

\author{
Chairoel Idris ${ }^{1}$, Mesiono $^{2}$ \\ ${ }^{1}$ Master Student of Islamic Education Management in FITK, UIN-SU, Indonesia \\ ${ }^{2}$ Lecturer in of Islamic Education Management in FITK, UIN-SU, Indonesia
}

\begin{abstract}
:
This research aims to explain: (1) the competence of leadership of MTs Al Manar Medan Head Master; (2) the quality of education MTs Al Manar medan; (3) the effectiveness of leadership's competence of MTs Al Manar Medan Head Master in improving the quality of education in MTs Al Manar Medan. This research was conducted by using qualitative descriptive approach. Research Subject is Head Master. The informants are Head Master, Vice of Head Master and Teachers. The data collection technique in this research is by: (1) Observation, (2) Interview, and (3) Documentation Study. Data Analysis Process is done by: Data Reduction, Display Data and Conclusion Drawing/Verification. The collected data is examined the validity of data by using Triangulation Data. The results of this research are: (1) Head Master's Leadership Competence of MTs Al Manar Medan include; (a) Personality Competencies, (b) Managerial Competencies, (c) Supervision Competencies, and (d) Social Competencies. (2) Quality of Education in MTs Al Manar Medan, Teachers are able to carry out the learning process well in accordance with the RPP that has been developed in accordance with the needs of schools, mastery of good learning media by teachers, discipline teachers and good students, students are able to follow the competitions in outside the school, the quality of graduates can compete with elite schools in Medan City. (3) The effectiveness of Headmaster Leadership Competence in Improving the Quality of Education includes: (a) Personality Competence, Head Master able to give good characters to teachers and students. (b) Managerial Competence, Head master able to makes annual program well, guide teachers and education personnel in performing tasks, motivate teachers to improve teacher professionalism, and maximize school's facilities and infrastructure. (c) Supervision Competencies, Head master evaluates the performance of teachers and education personnel on a regular basis at the end of every end years of learning, principals provide direct supervision during the learning process in the classroom. (d) Social Competence, headmaster participate in any activity within and outside the school.
\end{abstract}

Keywords :

leadership competence; education quality

\section{Introduction}

Education as a vital tool in the development of Human Resources, is a need that cannot be separated from human life in educating the life of the nation and forming skilled people in their fields. Other opinions also suggest that education in the sense of language is called the process of training and developing knowledge, skills, thoughts, behavior, etc. especially by formal schools. Education in this sense, in reality is often practiced with verbalistic teaching (Azizy, 2002: 18).

The embodiment of quality society is the responsibility of education, especially in preparing students to become subjects who increasingly have a role in displaying their strong, creative, independent and professional excellence in their respective fields. Efforts to improve the quality of education are continuously carried out both conventionally and innovatively. 
Schools that are well managed, in terms of learning, human resources, in this case educators and their management, will produce quality (graduate) outputs that are able to compete in places with greater challenges and are more complex. Meanwhile, schools with poor management will not provide good quality and graduates. Many schools are not managed in terms of learning and management systems so that these schools are not advanced and unable to compete in the education industry today.

To realize ideal schools and schools that meet the needs of the community in the field of education. So, schools or educational institutions need professional human resources. Human resources owned by schools can make a beneficial contribution to the implementation of effective education. The principal's leadership must be able to mobilize school resources, in relation to school program planning and evaluation, curriculum development, learning, management of personnel, advice and infrastructure, financial resources, student services, school and community relations and the creation of a school climate.

Decentralization and education autonomy require the involvement and empowerment of professional principals. Empowering the principal means functional improvement and competency of the principal so that the principal is able to play a role in accordance with the duties, authority, and responsibilities he carries. Specifically, school principals must have the ability to manage curriculum, student administration, human resources administration, administration of facilities and infrastructure, archival administration, and financial administration. These activities need to be carried out effectively and efficiently to support school performance. For this reason, principals must be able to describe their abilities and professional competencies in order to carry out operational tasks in the school environment.

Quality education is produced by quality leadership too, quality principals are professional principals. Professional school principals are school principals who are able to manage and develop schools comprehensively, therefore the principal has a very important and strategic role in realizing the school's vision, mission and goals. Principals who are professional in carrying out their duties are full of strategies to improve the quality of education, so as to produce quality outputs and outcomes.

Achievement of the goals of school education institutions is very dependent on the skills and leadership policies of the principal as an educational leader. The school principal is a professional official in managing the school organization as well as in charge of managing and managing all sources, organizations and in collaboration with school committees, the community, and other institutions and existing stakeholders. Principals in managing and developing schools must understand the needs of the school they lead, including the needs of teachers, students and school residents.

Professional school principals will always motivate all components of the school to improve their competencies so that the competencies of school residents can improve and develop well. Principals and teachers as professional education personnel do not only master the fields of science, teaching materials and learning methods. However, principals and teachers must be able to provide motivation to students to improve their quality and broaden the scientific insights that they must possess.

As a manager, the principal must be able to utilize all school resources in order to realize the vision and mission to achieve the goals set. In addition, the principal must be able to deal with various problems in the school, think analytically and conceptually and must always try to become 
a mediating teacher in solving various problems faced by the educators and educational staff who are subordinates, as well as trying to make satisfying decisions for all.

The principal must be able to describe the functions and objectives of National Education into more detailed goals. In other words, the goal becomes simpler and can be carried out. As managers, principals are required to be able and able to provide education services in accordance with what is expected by the community. Principals do not need to hesitate in making their own strategies and policies.

Madrasah Tsanawiyah Al Manar Medan is one of the educational institutions located at Karya Bakti street Medan District Johor City Medan which is one of the educational institutions under the auspices of the Al Manar Islamic Boarding School Foundation Medan. In 2010, the Al Manar Islamic Boarding School in Medan experienced a very significant set back, which had a negative impact on Medan Manastrian Al Manar Madrasah.

This is supported by data on the percentage of the number of students in the last 8 years obtained from madrasah documents that the number of students in 2010/2011 were 16 men and 7 women, so that the total number in the school year was only 23 students. The number continues to increase from year to year until the 2017/2018 school year the number of students in Madarasah Tsanawiyah Al Manar Medan is 118 men and 98 women, so that the total number of Madarasah Tsanawiyah Al Manar Medan students is 216 students.

\section{Literature Review}

\subsection{Leadership}

Leadership as a management function is very important to achieve organizational goals. With very heavy as if the leadership was forced to face various factors such as: structure or order, coalition, power, and environmental conditions of the organization. On the other hand, leadership seems to easily become an extraordinary tool for solving any problems that are affecting an organization (Wahjosumidjo: 2003, 15).

The definition of leadership cited by Fred E, Fieldler and Martin M. Chemers in Wahjusumidjo is as follows:

a. Leadership is the exercises of authory and the making of decisions (Dubin, 1951).

b. Leadership is the initiation of acts that result in a consistent pattern of group interaction directed toward the solution of matual problems (Humphill, 1954).

c. Leadership is the procces of influenching group activities toward goal setting and goal achievement (Stogdill, 1948).

From the various limits on the notion of leadership above that leadership is the activity of the holders of power in influencing group activities in decision making, formulation and achievement of goals in an organization, as well as being able to solve problems within the organization.

The above was also stated by Rohiat that leadership is the ability to create the most effective changes in group behavior; for others it is the process of influencing group activities toward setting goals and achieving goals (Rohiat, 2008: 14). In other words, that a leader must be able to influence the people he leads to carry out all orders or rules made by an institution, in this case the educational institution to achieve the expected goals. 
Various changes that occur in the world of education such as changes in education management due to government policies regarding education and curriculum changes, methodological changes that are directed at effective and enjoyable learning, demands for teacher qualifications and education personnel to be more professional. The discussion in this section focuses on professional educational leadership, the characteristics of future leadership, effective leadership in determining policies, the ability of leaders to delegate, the leadership competencies of madrasah principals, democratic attitudes developed by principals as leaders of principals' leadership in the democratic system .

Thus, the leader is the person responsible and guide, direct the performance and activities; the followers are people who carry out an activity with the direction and guidance of a leader and also direct them to always walk the request of Allah SWT and stay away from His prohibitions, and are able to have a far-sighted view to improve the educational institutions they lead.

\subsection{Principal Competency Standards}

On April 17, 2007, the Minister of National Education issued Minister of National Education Regulation No. 13 of 2007, concerning Principal / Madrasah Standards. That in order to be appointed as the principal of a school / madrasah, a person must meet the national standard of the school / madrasah. The standard consists of General Qualifications, special qualifications, managerial competencies, personality competencies, entrepreneurial competencies, supervisory competencies and social competencies.

Indeed this is very normative, not implied about the perspective or background of motivation to filter it so that it raises principals with high dedication. It becomes very interesting indeed if in the interview or selection there are things that can reveal this so that the principal also has standard capabilities that are not too different from one another as well as a benchmark of education in the school they are in.

Besides of course the real encouragement from the government so that it is not only seen as a career or structural position but has a passion to advance schooling education despite the shortcomings that always arise, even though it is only fairness.

In the 2007 fiscal year, the Minister of National Education of the Republic of Indonesia issued national standard No. 13 of 2007 concerning Principal / Madrasah Standards. These standards are as follows (Permendiknas: 2007):

Personality

1) Having good morals, developing a culture and tradition of noble morals, and being a role model of noble morals for the community in schools / madrasas.

2) Having the integrity of personality as a leader.

3) Have a strong desire in self-development as a school / madrasa principal.

4) Be open in carrying out basic tasks and functions.

5) Controlling yourself in facing problems at work as a school / madrasa principal.

6) Has the talent and interest in the position as an educational leader leads.

\section{Research Methodology}

As for the place of this research, it was held in the Al Manar Medan Private Madrasah Tsanawiyah located at Jalan. Bakti No. 34 Pangkalan Masyur Medan Johor District 20143 Medan City North Sumatera (Zamachsyari and Thayyib, 2014: 1). The time of this research will be conducted from 10 October 2017 to 15 March 2018. 
The background of this research is that Madrasah Tsanawiyah Al Manar Medan is one of the educational institutions under the auspices of the Al Manar Islamic Boarding School Foundation. Al Manar Islamic Boarding School is one of the leading Islamic boarding schools in the city of Medan. However, recently, the Al Manar Islamic Boarding School has experienced a very significant setback, which has resulted in many students choosing to move to other educational institutions both in Medan and outside Medan.

\section{Discussion}

The principal function of the principal as the leader of an educational institution is to create a teaching and learning situation, so that teachers can teach and students can learn well. In carrying out this function, the principal has a dual responsibility, namely to carry out school administration so as to create a good teaching and learning situation, and to carry out supervision so that the ability of teachers increases in guiding the growth of their students (Rosmiati and Achmad, 2009: 141).

Effectiveness means the effectiveness or results of use or support the goals achieved (Pius Abdillah, 2008, 110). Where as in the big Indonesian dictionary effectiveness is defined as things that have an effect or have an effect on something (KBBI, 2008: 375). From the above understanding, it can be concluded that effectiveness is the efficiency possessed by something that is able to deliver something to achieve the stated goals.

The leadership of the Head of Madrasah Tsanawiyah Al Manar Medan with his personal competence is able to give influence to the teachers and education staff in carrying out educational tasks in the madrasah. Teachers and education personnel in carrying out their work feel comfortable. This is the guidance given by the headmaster to them.

The madrasa head also gives freedom to teachers and education personnel to increase their professionalism in carrying out their duties in the madrasa by involving teachers and education personnel to take part in activities to increase the professionalism of teachers and education personnel, both organized by the city / district government and institutions other quality assurance for education.

The headmaster of the madrasa also provides oversight to educators and education staff in implementing learning in the classroom, so that teachers are serious in implementing learning, both using instructional media and classroom mastery. The madrasah head also conducts work evaluations of teachers and education personnel every two weeks in a month on Saturday afternoons and is carried out at the end of each even and odd semester. This was done to achieve the objectives of education and the quality of education in Madrasah Tsanawiyah Al Manar Medan.

The madrasah head also cooperates with certain institutions in improving the welfare of teachers and education personnel in Madrasah Tsanawiyah Al Manar Medan. Namely by establishing cooperation with educational institutions such as Dharmawangsa, BMT Financial institutions, Bank Aceh and other religious institutions.

The effectiveness of the leadership competence of the Head of the Madrasah Tsanawiyah Al Manar Medan can be seen from the family system built in the Madrasah Tsanawiyah Al Manar Medan, the implementation of the annual program, the quality of good learning, and the quality of 
graduates who are able to compete in continuing education to favorite educational institutions in Medan City and outside the city.

From the theory and research results above, it can be concluded that the effectiveness of the competence of madrasah principals in improving the quality of education in Madrasah Tsanawiyah Al Manar Medan includes: 1) School Principals have professionalism as educators and to motivate teachers to have professionalism as teachers. 2) As a manager, the principal performs a good management function, the school is able to manage the organization so that management is effective. 3) The role and function as an administrator runs well, it is proven, with physical evidence in the form of school administration management as an indicator. 4) The role and function of the principal as a supervisor runs quite well, with a supervision program for teachers and staff and the role of supervision felt by teachers and staff as a means to improve performance in learning and working in school. 5) The role and function of the principal as a leader goes well. The principal has integrity, commitment to discipline, consistency and democracy. As the principal, the school organization understands the principal, vision and mission characteristics of the Permata Bunda Integrated Islamic Primary School. 6) The role and function as the head creator of the working climate goes well. The headmaster always strives for a conducive work environment for teachers and CPNS, so that optimal productivity in the workplace.

\section{Conclusions}

Headmaster of Madrasah Tsanawiyah Al Manar Medan already has leadership competence in accordance with Minister of Education Regulation No. 13 of 2007 which includes; (1) Personality Competence; (2) Managerial Competence; (3) Supervision Competencies; and (4) Social Competence. The quality of education in Madrasah Tsanawiyah Al Manar Medan is good. It can be seen from the ability of teachers to carry out learning well, teachers are also able to create innovative and fun learning. The ability of Madrasah Tsanawiyah Al Manar Medan students in competing with advanced schools in Medan, both from the fields of social science, science, arts and sports. The effectiveness of the Leadership Competence of Head of Madrasah Tsanawiyah Al Manar Medan can improve the quality of education in Madrasah Tsanawiyah Al Manar Medan.

\section{References}

Abdillah, Pius. Kamus Islmiah. Surabaya: Arkoal, 2008

Arief, S. Sadiman Dkk, Media Pendidikan, Pengertian, Pengembangan dan Pemanfaatannya, Jakarta: PT Rajawali Pers, 2009

Azizy, Qodri. Pendidikan (Agama) untk Membangun Etika Sosial. Semarang: Aneka Ilmu, 2002

Bakhtiar, Amsal, Filsafat Agama. Jakarta: Logis Wacana Ilmu, 1997

Departemen Agama RI. Al-Qur'an dan Terjemahannya. Bandung: Syamil Al-Qur'an. 2005

Departemen Pendidikan Nasional. Manajemen Peningkatan Mutu Berbasis Sekolah. Jakarta: Proyek Peningkatan Mutu SMU Jakarta, 2001

Emzir, Analisis Data: Metodologi Penelitian Kualitatif. Jakarta: Rajawali Pers, 2010

Fadjar, Malik. Visi Pembaruan Pendidikan Islam. Jakarta: LP3NI, 1998

Fuad, Muhammad. AlLu'lu' Wal Marzan Hadist-Hadist Pilihan yang Disepakati Al-Bukhari dan Muslim. Jakarta: Pustaka Al-Kautsar, 2002

Hidayat, Rahmat dan Candra Wijaya. Ayat-Ayat AlQur'an Tentang Manajemen Pendidikan Islam.

Medan: Lembaga Peduli Pengembangan Pendidikan Indonesia (LPPPI). 2017

http://www.mediapendidikan.info/wpcontent/uploads/2014/12/permendiknas 13Tahun 200

7-sks lamp.pdf, access on 27-11.2017 at 07.21

Iskandar, Metodologi Penelitian dan Pendidikan dan Sosial. Jakarta: GP. Press, 2009 
Masnur, Muslich, KTPS (Kurikulum Tingkat Satuan Pendidikan) Dasar Pemahaman dan Pengembangan, Jakarta: Bumi Aksara, 2009, five print

Moleong, Lexy J. Metodologi Penelitian Kualitatif, Bandung: PT Remaja Rosdakarya, 1999

Mulyasa, Kurikulum Berbasis Kompetensi, Bandung: PT. Remaja Rosdakarya, 2004

Mulyasa. Manajemen Berbasis Sekolah: Konsep, Strategi dan Implementasi. Bandung: Rosdakarya, 2002

Mulyasa. Menjadi Kepala Sekolah Profesional dalam Kontek Menyukseskan MBS dan KBK. Bandung: Remaja Rosdakarya, 2007

Poerdarminta,WJS. Kamus Umum Bahasa Indonesia. Jakarta: Balai Pustaka, 1976

Priansa, Donni Juni. Manajemen Supervisi dan Kepala Sekolah. Bandung: Alfabeta, 2014

Pusat Bahasa Departemen Pendidikan Nasional. Kamus Besar Bahasa Indonesia. Jakarta: Pusat Bahasa, 2008

Ramayulis. Imu Pendidikan Islam. Jakarta: Kalam Mulia, 2004

Rohiat. Kecerdasan Emosional Kepala Sekolah. Bandung: Efika Aditama, 2008

Rosmiati, Tatty, Kepemimpinan Pendidikan dalam Manajemen Pendidikan, Bandung: Alfabeta, 2009

Rosyada, Dede, Paradigm Pendidikan Demokrasi Sebuah Model Pelibatan Masyarakat dalam Penyelenggaraan Pendidikan. Jakarta: Kencan Prenada Media Group, 2007, third print

Sagala, Syaiful. Human Capital Membangun Modal Sumber Daya Manusia Berkarakter Unggul Melalui Pendidikan Berkualitas. Depok: Kharisma Putra Mandiri, 2017

Saragih, Nasiruddin. Hasil Wawancara Kepala Madrasah Tsanawiyah Al Manar Medan. Kantor Kepala Madrasah: Friday, 03 March 2018

Sugiono. Metode Penelitian Kuantitatif dan Kualitatif. Bandung: Alfabeta, 2012

Suharsaputra, Uhar. Administrasi Pendidikan Edisi Revisi. Bandung: Refike Aditama, 2013

Syafaruddin. Manajemen Lembaga Pendidikan Islam. Jakarta: Ciputat Press, 2005

Thayyib, Zamakhsyari Dkk. Profil Pesantren Al-Manar Medan. Medan, 2014

Usman, Husaini. Kepemimpinan Berkarakter Sebagai Model Pendidikan Karakter. Jurnal Pendidikan Karakter, Tahun III, Nomor 3, Oktober 2013.Access on 26 May 2018

Wahjosumidjo, Kepemimpinan Kepala Sekolah Tinjanan Teoritik dan Permasalabnnya, Jakarta: Rajagrafindo Persada, 2010 